\title{
Application of Classroom Response Systems (CRS): Study to Measure Student Learning Outcome
}

\author{
https://doi.org/10.3991/ijet.v14i14.10506 \\ Hairus Saleh ${ }^{(\varpi)}$ \\ Universitas Madura, Madura, Indonesia \\ hairuss_math@unira.ac.id \\ Nurdyansyah, Fitria Nur Hasanah \\ Universitas Muhammadiyah Sidoarjo, Sidoarjo, Indonesia \\ Hendra Erik Rudyanto \\ Universitas PGRI Madiun, Madiun, Indonesia \\ Mu'alimin \\ Institut Agama Islam Negeri Jember, Jember, Indonesia
}

\begin{abstract}
Classroom Response Systems is a scanner system in the form of technology that is used in the classroom, which allows students to answer a question with an input directly inputted into the data, so that the application of learning outcome measurement becomes effective and efficient. This study uses qualitative methods and is implemented in 120 students and is a formative research. This study describes the use of Classroom Response Systems (CRS) when measuring student learning outcomes. The research subjects were students of the Mathematics Education and Elementary School Teacher Education Department who had heterogeneous abilities. Research findings show that students consider CRS can improve class dynamics in theoretical lectures. On the other hand, almost all students have agreed with the assertion that CRS is easy to use, although some of them have warned that recipients do not always record their responses.
\end{abstract}

Keywords - Classroom Response Systems, Clickers, Learning Outcome

\section{$1 \quad$ Introduction}

Over the past 15 years, teachers input data by correcting students' answers manually one by one and spending lots of paper, which causes pollution. To reduce paper use, technology-based learning systems are needed. This can be started from measuring learning outcomes, because large classes take a long time if the measurement of learning outcomes is done manually. This can also inhibit the giving of feedback to students, so that a system that is accurate and precise in measuring student learning 
outcomes. IT and communication in learning play an important role to facilitate the by teachers to students [1], and its application can have a potential impact that can improve the quality of learning [2].

Many efforts can be taken by the teacher to overcome the problem. One effort that can be taken is the use of technology when measuring student learning outcomes as it has now developed, the classroom response systems (CRS) [3], [4]

CRS is a scanner system that is used in the class to allow students to answer a question easily [5] with the answers directly inputted into the data, so that the application of learning outcome measurements becomes effective and efficient. CRS is an interactive technology that allows instructors to ask questions and immediately collect responses from all classes [3]. The system automatically calculates the response and instantly projects the results in a graphical format for the entire class to see. This system has evolved over the past 15 years. This system can use an application called Plickers that is accessible to everyone.

Students may feel intimidated by fellow students because of prior knowledge of the object. Anonymity and direct feedback are the main advantages of the plickers response system [6], [7]. Each student can answer each question without fear of embarrassment if their answer is incorrect. This greatly increases students' willingness to participate in class more than just traditional question and answer processes. In addition, plickers also offer fun diversions during college making time spent more attractive to students and lecturers [8], [9]

\section{Method}

The method used in this study is qualitative, so the data obtained in this study is also qualitative [10], which is in the form of development data and student learning outcomes. The instrument used is the questions inputted into Plickers. This research was carried out on 120 students consisting of 30 students of mathematics education program in Universitas Madura, Elementary Teacher Education in Universitas PGRI Madiun, Islamic Education in Universitas Muhammdiyah Sidoarjo and Institut Agama Islam Negeri Jember respectively.

It is important to emphasize that in the perspective of this research, research subjects must understand that the value in this study is formative (not summative) and during this research process, feedback are needed to be given to subjects such as in further technological development. 


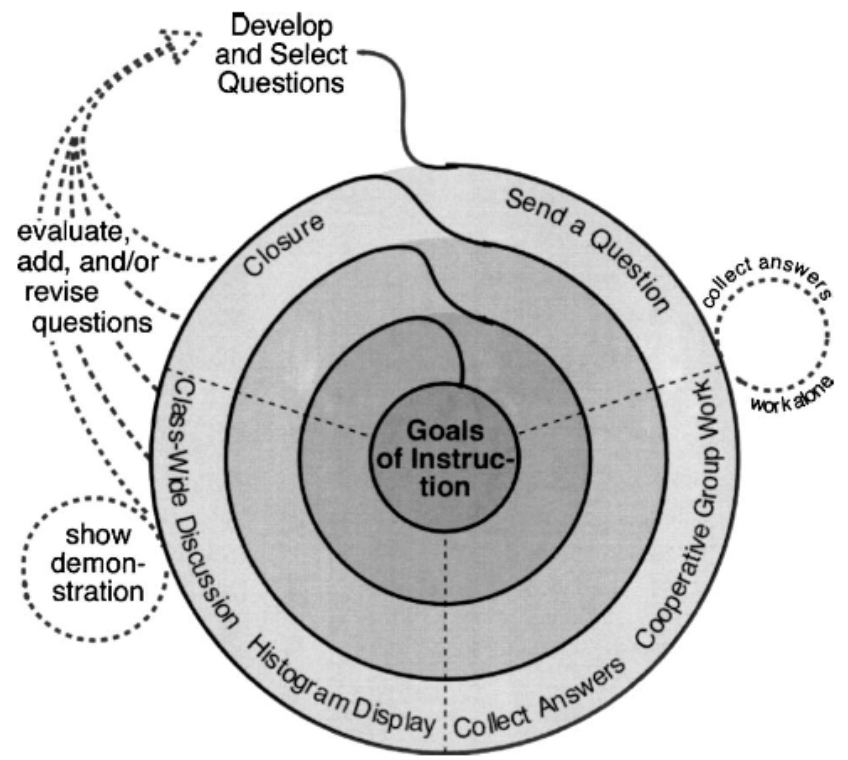

Fig. 1. The question cycle used for question-driven instruction with a classroom response system. (Adapted from Beatty 2006)

Figure 1 shows the process of using classroom response systems to make questions in a test to measure student learning outcomes. To achieve the results of an instruction, there are several stages that must be gone through, which are sending questions or questions, gathering answers, and then discussing together and revising or probably adding questions.

\section{$3 \quad$ Result and Discussion}

\subsection{Contructing classroom response systems on plickers}

The ease of technology nowadays makes classroom response systems can be made through websites from an application that has been developed previously, namely Plickers. This program consists of a barcode for each student and some data inputted through the website such as student name data and questions that will be given to students.

Figure 1 shows the first page of using plickers on the website. Figure 2 shows the process of inputting student name data in a class, while Figure 3 shows the process of inputting problem data and answers. The correct answer will be marked in green. Answers can also be automatically shuffled by clicking "shuffle choice". 


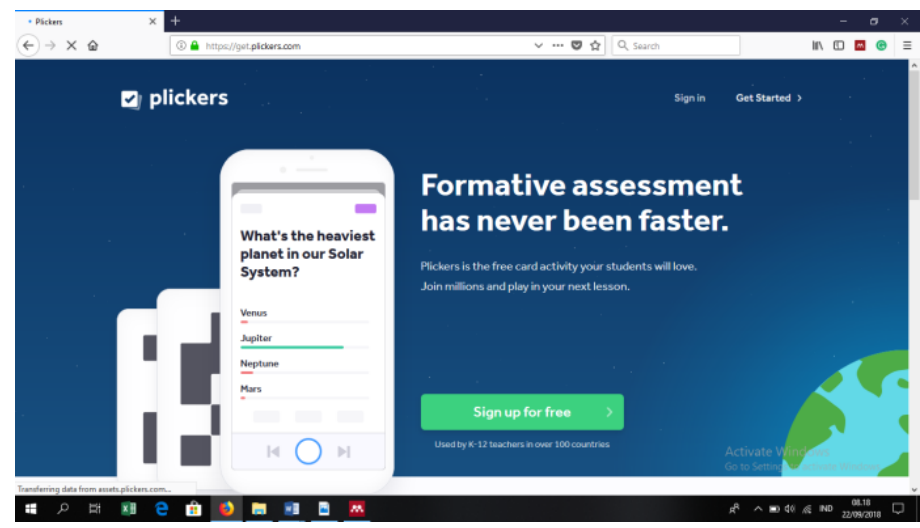

Fig. 2. Preface of Plicker initial page

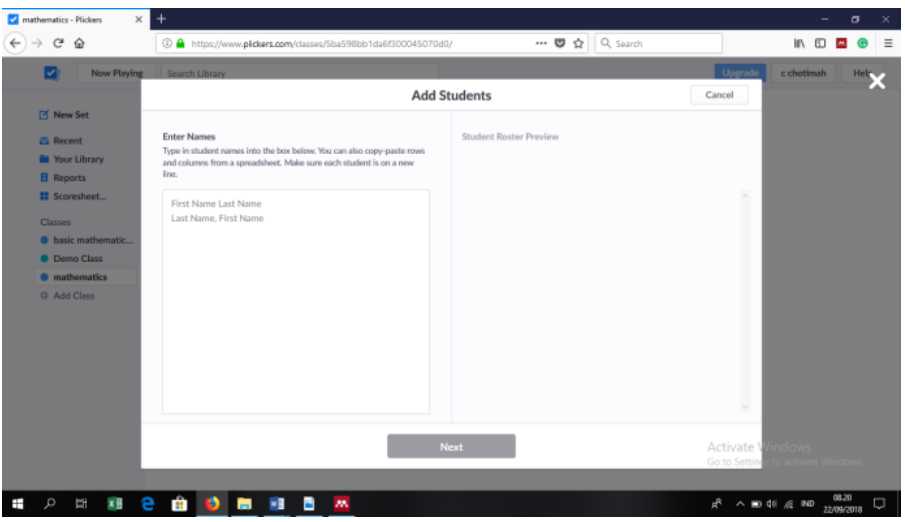

Fig. 3. Preface to input students' data

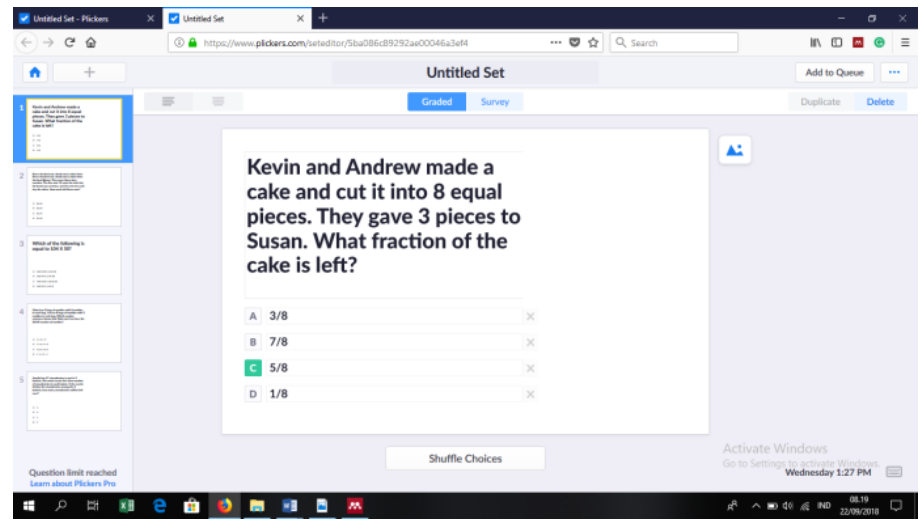

Fig. 4. Preface to input questions and answers 
In figure 3 show what the mataries for this research in this question is about fraction. Not only for fraction, this systems can make student to have choose a better choice in mathematic logic. With a new system that can make student develop their skills in mathematic logic with classroom response systems through Plickers.

After constructing classroom response systems through Plickers, the application is validated with several categories, which are usefulness, efficiency, functionality, portability, and learning content [11]. Usability, efficiency, functionality and portability are validated by 3 technology expert lecturers, while learning content is validated by 3 education expert lecturers.

Table 1. The result of interactive mathematics multimedia validation

\begin{tabular}{|c|l|c|l|}
\hline No. & \multicolumn{1}{|c|}{ Aspects } & Scale & \multicolumn{1}{c|}{ Criteria } \\
\hline 1 & functionality & 4.3 & Very Good \\
\hline 2 & usability & 4.5 & Very Good \\
\hline 3 & efficiency & 4.43 & Very Good \\
\hline 4 & portability & 4.13 & Good \\
\hline 5 & Learning content & 4.5 & Very Good \\
\hline Average & 4.372 & Very Good \\
\hline
\end{tabular}

Table 1 shows the results of the validation of several experts with a maximum scale of 5, while the average results obtained are 4,372 which are categorized with Arikunto conversion calculations are considered as very good [12].

\subsection{Plickers usage}

The use of plickers is easy. Students are only needed to carry and play a barcode in Figure 4, which is different for each student. The barcode is paired with the name of the student who has been inputted on the website as shown in Figure 2. The barcode can be downloaded on the plicker website. Barcode classification is divided into three, namely regular, medium, and large. The regular one consists of 40 barcodes, the medium consists of 100 barcodes, while the large one consists of 200 barcodes. We can adjust the needs of students only with these three categories.

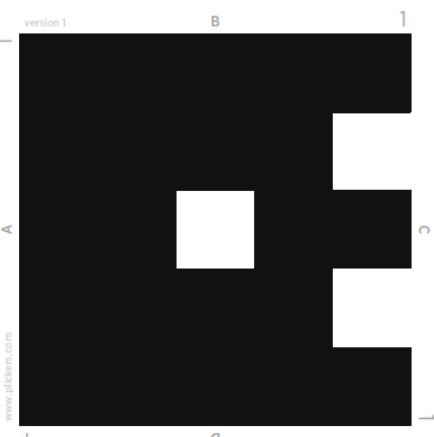

Fig. 5. Students barcode 
It can be seen that there is a number 1 on the barcode that represents the student number or subject number that has been inputted on the website. To make things easier, $\mathrm{i}$ i's better to use student register number the in school data. The letter of ABCD represents the student's multiple choice answers, while the letter above is the correct answer according to students.

When implementing classroom response systems through plickers, the names of students who have given their answers and how many students have given their answers will look like in Figure 5. In the figure, there are numbers that indicate the number of students who have answered the question. If there are students who have not answered, they will be visible through the computer.

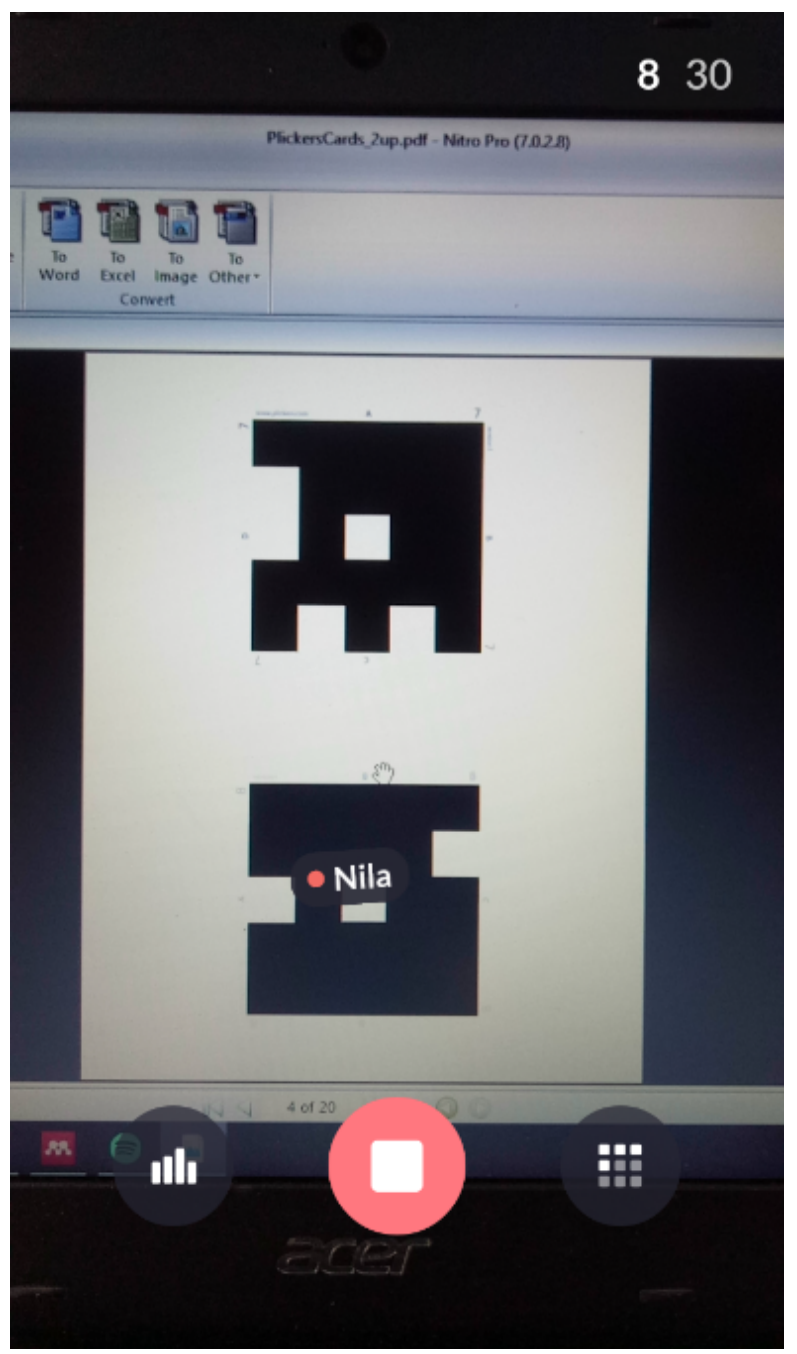

Fig. 6. Scanning of student barcode 


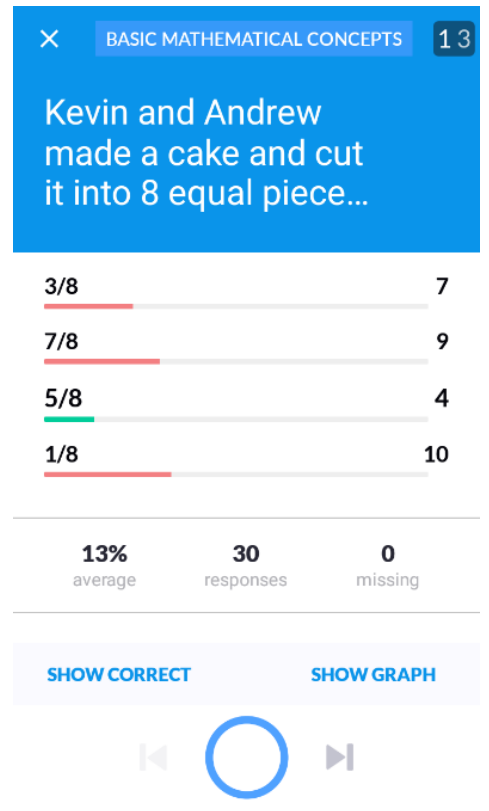

Fig. 7. Answer result diagram of the question

After the process of scanning students 'answers from the barcodes, a diagram of the results of the students' answers is obtained. The diagram shows how many percent of students answered correctly as in Figure 6.

Figure 7 shows the value of problem number 1 for each student with $20 \%$ correct score due to the fact that there are 5 questions in this test and $0 \%$ wrong value. Figure 8 shows student learning outcomes in the overall test. All values can be seen, from the highest to the lowest.

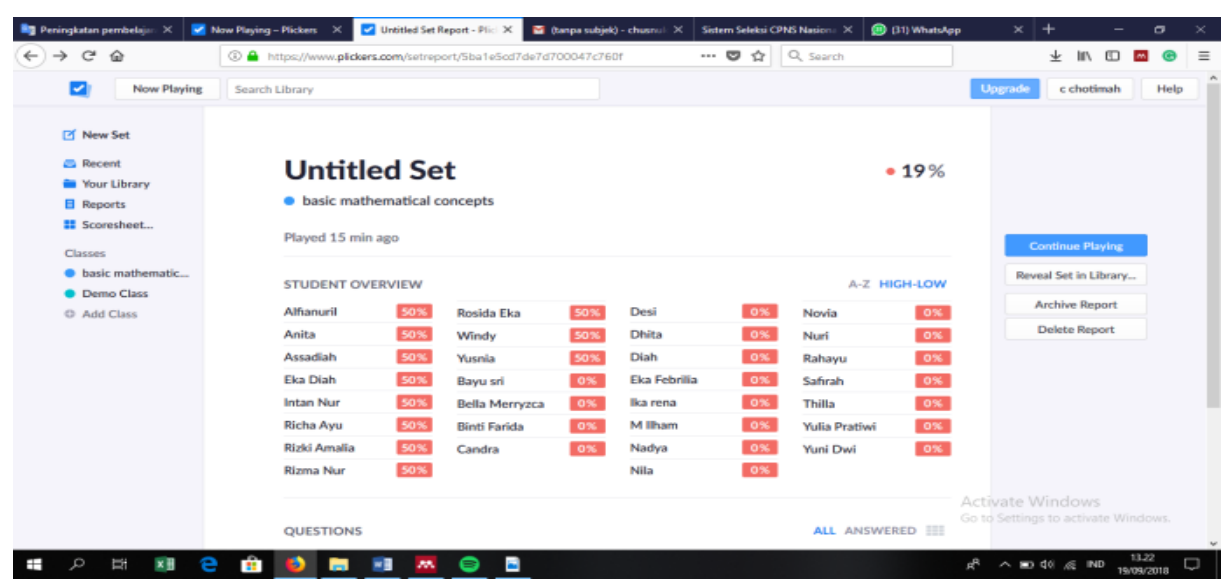

Fig. 8. Result or student answers in the question 


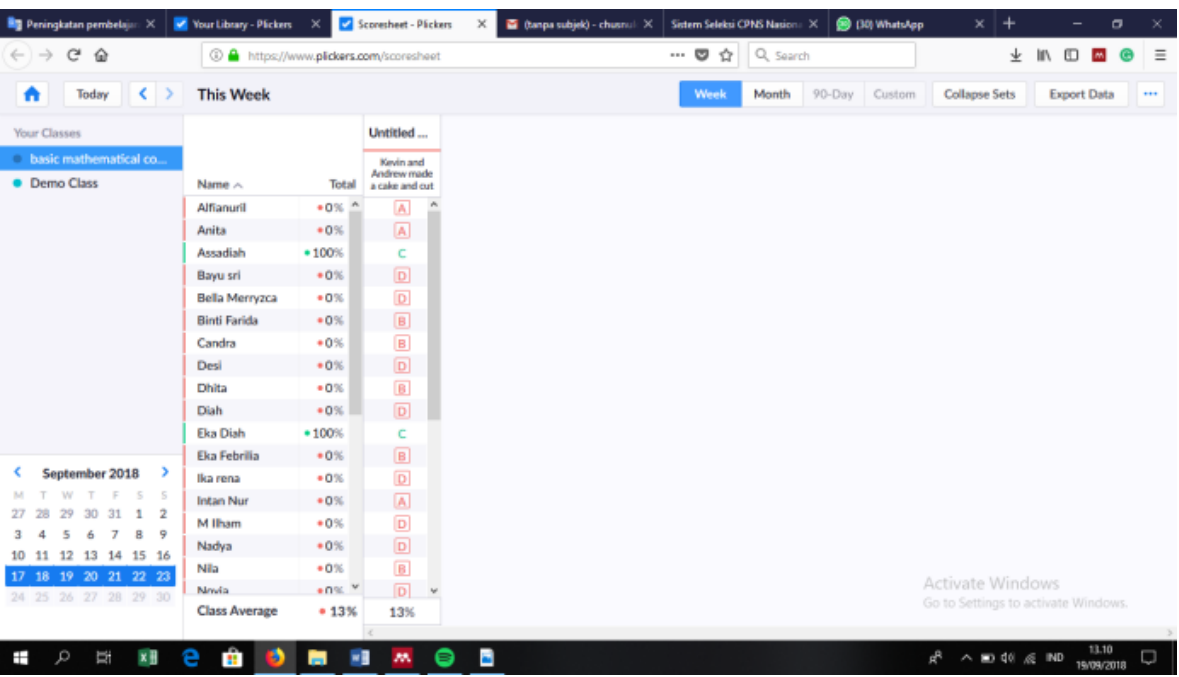

Fig. 9. Score sheet of a class

\subsection{Discussion}

The scoresheet on student test results creates usefulness and efficiency in using technology to measure student learning outcomes. CRS makes it easy for teachers or lecturers to measure student learning outcomes just by using one sheet of paper for each student.

Data from CRS can also facilitate learning as a measuring tool for student learning outcomes. The ability of CRS to gather understanding from students and find out changes in student knowledge through an effective system allows this system to be used for research and to collect learning documents.

Some research states that CRS can make students more attentive and focused when answering questions [13] [14], so that student learning outcomes can be collected quickly and do not require preparation for the old class. Some other research states that by using CRS, students think individually so that there is a lack of group ability [7].

That is also the result of this study. Students work on questions individually but they experience ease in determining answers and focus on reading questions and thinking about these answers.

Research shows increased learning based on the use of 2 electronic voice systems in classrooms [15] suggesting that this might be a useful tool for improving student learning. In addition, direct feedback will be available to students through the use of Plickers. Finally, the use of multiple choice questionnaires for examinations was introduced this year as an adaptive strategy assessment of various levels of learning outcomes [8].

Learning by operating technology is facilitated by CRS-based learning [16]. The use of manual systems is more difficult because they involve adding and matching between answers with questions manually, calculating answers from students, and several other things that are done manually [17]. 
In the question-driven instruction approach, the use of CSR to pose, gather answers, and discuss questions, forms the main points of instruction in the classroom. The success of the approach depends in part on the quality of the questions used. Effective questions must be designed with clear pedagogic objectives and have three elements consisting of content objectives, processes (cognitive), and metacognitive goals. The purpose of the content is the subject matter to be discussed. In general, it must be conceptual and fundamental and must often integrate ideas from various parts of the curriculum [16].

Fies and Marshall stated that research is limited regarding the use of School Response Systems (SRS) for formative assessment [18]. This is especially true in elementary and secondary schools. However, an exploration research conducted by Polly, et al. found that using SRS in basic math classes helps teachers with formative assessment by providing data to inform the direction of instruction and track student progress [19]. Therefore, the use of quizzes in the classroom using Plickers as a teaching strategy is considered in line with the assessment method.

Regarding the relationship between CRS and learning, almost all students have reported that the tool allows them to get quick feedback about their responses, providing instant monitoring of their learning during lectures [20]. Although some research has stated that this system also carries all kinds of obstacles to their learning, the majority of participants consider that, at some level, this system contributes to better knowledge than mere theoretical concepts.

\section{Conclusion}

This study explains the use of CSR when measuring student learning outcomes. The findings indicate that students consider that CRS improves the dynamics of the class in theoretical lectures [18] [21]. On the other hand, almost all students have agreed with the assertion that CRS is easy to use, although some of them have warned that recipients do not always record their responses [20]. This study explains the use of CSR when measuring student learning outcomes. The findings indicate that students consider that CRS improves the dynamics of the class in theoretical lectures [18] [21]. On the other hand, almost all students have agreed with the assertion that CRS is easy to use, although some of them have warned that recipients do not always record their responses [20].

\section{$5 \quad$ References}

[1] T. Listyorini and R. Rahim, "A prototype fire detection implemented using the Internet of Things and fuzzy logic," World Trans. Eng. Technol. Educ., vol. 16, no. 1, pp. 42-46, 2018.

[2] M. F. Amir, F. N. Hasanah, and H. Musthofa, "Interactive Multimedia Based Mathematics Problem Solving to Develop Student s ' Reasoning," Int. J. Eng. Technol., vol. 7, no. 2.14, pp. 272-276, 2018.

[3] A. Deal, A Teaching with Technology White Paper: Classroom Response Systems. Pennsylvania: Office of Technology for Education Carnegie Mellon University, 2007. 
[4] Dublin Institute of Technology, Enhancement of learning with classroom response systems ( clickers ). Dublin: Dublin Institute of Technology, 2011.

[5] J. Berry, "Technology support in nursing education: clickers in classroom," Nurs. Educ. Perspect., vol. 30, no. 5, pp. 295-298, 2009.

[6] M. E. Emenike and T. A. Holme, "Classroom Response Systems Have Not 'Crossed the Chasm ' : Estimating Numbers of Chemistry Faculty Who Use Clickers," J. Chem. Educ., vol. 89, pp. 465-469, 2012. https://doi.org/10.1021/ed200207p

[7] H. L. Dangel and C. X. Wang, "Student Response Systems in Higher Education : Moving Beyond Linear Teaching and Surface Learning," J. Educ. Technol. Dev. Exch., vol. 1, no. 1, pp. 93-104, 2008.

[8] S. J. Burton, R. R. Sudweeks, P. F. Merrill, and B. Wood, How to Prepare Better Multiple-Choice Test Items: Guidelines for University Faculty. Brigham: Brigham Young University Testing Services, 1991.

[9] D. M. Bunce, E. A. Flens, K. Y. Neiles, and U. States, "Study of Student Attention Decline Using Clickers," J. Chem. Educ., vol. 87, no. 12, pp. 1438-1443, 2010. https://doi.org/10.10 21/ed100409p

[10] Sugiyono, Metode Penelitian Kuantitatif, kualitatif dan R \& D. Bandung: Alfabeta, 2013.

[11] N. Nasrudin, I. Agustina, A. Akrim, A. S. Ahmar, and R. Rahim, "Multimedia educational game approach for psychological conditional," Int. J. Eng. Technol., vol. 7, no. 2, pp. 78-81, 2018.

[12] S. Arikunto, Prosedur Penelitian. Jakarta: Rineka Cipta, 2012.

[13] S. A. Yourstone, H. S. Kraye, and G. Albaum, "Classroom questioning with immediate electronic response: Do clickers improve learning?," Decis. Sci. J. Innov. Educ., vol. 6, no. 1, pp. 75-88, 2008. https://doi.org/10.1111/j.1540-4609.2007.00166.x

[14] J. E. Caldwell, "Clickers in the large classroom: Current research and best-practice tips," CBE-Life Sci. Educ., vol. 6, no. 1, pp. 9-20, 2007. https://doi.org/10.1187/cbe.06-12-0205

[15] G. Masikunis, A. Panayiotidis, and L. Burke, "Changing the Nature of Lectures Using a Personal Response system,” Innov. Educ. Teach. Int., vol. 46, no. 2, pp. 199-212, 2009. https://doi.org/10.1080/14703290902843935

[16] I. D. Beatty et al., "Designing effective questions for classroom response system teaching Designing effective questions for classroom response system teaching," Am. J. Phys., vol. 74, no. 1, pp. 31-39, 2006. https://doi.org/10.1119/1.2121753

[17] A. Feldman and B. Capobianco, "Real-time formative assessment: A study of teachers' use of an electronic response system to facilitate serious discussion about physics concepts," in Annual Meeting of the American Educational Research Association, 2003.

[18] C. Fies and J. Marshall, "Classroom Response Systems : A Review of the Literature," J. Sci. Educ. Technol., vol. 15, no. 1, pp. 101-109, 2006.

[19] D. Polly, J. R. Mcgee, C. Wang, C. Martin, R. Lambert, and D. Pugalee, "Linking Professional Development, Teacher Outcomes, and Student Achievement: The Case of a Learner-Centered Mathematics Program for Elementary School Teachers," Int. J. Educ. Res., vol. 72, 2015. https://doi.org/10.1016/j.ijer.2015.04.002

[20] J. L. López-quintero, M. Varo-martínez, A. M. Laguna-luna, and A. Pontes-pedrajas, "Opinions on 'Classroom Response System ' by first -year engineering students," Procedia - Soc. Behav. Sci., vol. 228, no. June, pp. 183-189, 2016. https://doi.org/10.1016/j.sbs pro.2016.07.027

[21] J. D. Benson, K. A. Szucs, and M. Taylor, "Student Response Systems and Learning : Perceptions of the Student," Occup. Ther. Heal. Care, 2016.

\section{Authors}

Hairus Saleh is a lecturer in the mathematics education department at Universitas Madura from 2014 until now. He is now pursuing a doctoral degree in mathematics education at Malang state university, Indonesia. Topics that are often used as research 
are about mathematics education in various fields, such as mathematics in learning media in technology and problem solving in mathematic

Nurdyansyah was born in Kediri, March 12, 1985. Undergraduate education was completed in the Social Science Education Study Program, Islamic State University of Malang in 2008. S2 education in the Islamic Elementary Education Postgraduate Program was completed in 2010. In 2015, the author continued S3 Education Department of Tekcmology Education at the State University of Surabaya and is still in the study period. In 2015 the author continued his career to become a permanent Lecturer in Islamic Education Study Program at Universitas Muhammadiyah Sidoarjo. Both authors' parents are teachers, which is what makes the writer interested in becoming an educator. Because actually being a teacher is a call, and a professional teacher is the best teacher in the eyes of children.

Fitria Nur Hasanah is a lecturer at the Department of Information Technology Education at Universitas Muhammadiyah Sidoarjo since 2016 until now. Her educational background is Diploma in Information Management, Bachelor of Informatics Engineering Education, and Masters in Vocational Education, Information Concentration. Her research interested in researching about the problems of education and media development in the field of informatics.

Hendra Erik Rudyanto is a lecturer in the education department of elementary school teachers at Universitas PGRI Madiun from 2012 until now. He is now pursuing a doctoral degree in primary education at Yogyakarta State University, Indonesia. Research topics are often used are mathematics education especially in elementary school, such as elementry student's creative thinking ability, ethnomathematics learning in elementary school, and learning technology media.

Mu'alimin was born in Lamongan, February 4, 1975. Undergraduate education was completed in the education of islamic religion Study Program, STAIN Malang in 1998. S2 education in the islamic religion Postgraduate Program at University of Muhammadiyah Sidoarjo was completed in 2007. In 2008, the author continued S3 Islamic Education Managament at Maliki State Islamic University the of Malang was completed in 2018. The author began his career at supervisor of education (Madrasah) Pasuruan. Furthermore, in 2018 the author continued his career to become a permanent Lecturer in Faculty of Education and Teacher Training IAIN Jember.

Article submitted 2019-03-21. Resubmitted 2019-05-25. Final acceptance 2019-05-26. Final version published as submitted by the authors. 